\title{
Building capacity towards what? Proposing a framework for the analysis of energy transition governance in the context of urban informality in Sub-Saharan Africa
}

\section{Zora Kovacic, Josephine Kaviti Musango, Kareem Buyana, Amollo Ambole,} Suzanne Smit, Baraka Mwau, Madara Ogot, Shuaib Lwasa \& Alan Brent

To cite this article: Zora Kovacic, Josephine Kaviti Musango, Kareem Buyana, Amollo Ambole, Suzanne Smit, Baraka Mwau, Madara Ogot, Shuaib Lwasa \& Alan Brent (2021) Building capacity towards what? Proposing a framework for the analysis of energy transition governance in the context of urban informality in Sub-Saharan Africa, Local Environment, 26:3, 364-378, DOI: 10.1080/13549839.2020.1849075

To link to this article: https://doi.org/10.1080/13549839.2020.1849075

册 Published online: 30 Nov 2020.

Џll Article views: 172
Submit your article to this journal $\pi$ 


\title{
Building capacity towards what? Proposing a framework for the analysis of energy transition governance in the context of urban informality in Sub-Saharan Africa
}

\author{
Zora Kovacic (Di) ${ }^{a}$, Josephine Kaviti Musango ${ }^{a}$, Kareem Buyana $\mathbb{D}^{b}$, Amollo Ambole ${ }^{c}$, \\ Suzanne Smit ${ }^{a}$, Baraka Mwau ${ }^{d}$, Madara Ogot ${ }^{e}$, Shuaib Lwasa ${ }^{b}$ and Alan Brent (i) ${ }^{f, g}$ \\ aUrban Modelling and Metabolism Assessment (uMAMA), School of Public Leadership, Stellenbosch University, \\ Stellenbosch, South Africa; ${ }^{b}$ Urban Action Lab, CHUSS Building, Makerere University, Kampala, Uganda; 'School of \\ the Arts and Design, University of Nairobi, Nairobi City, Kenya; ${ }^{d}$ Planning Consultant, Nairobi, Kenya; ${ }^{e}$ Department \\ of Mechanical \& Manufacturing Engineering, University of Nairobi, Nairobi City, Kenya; ${ }^{f} C e n t r e$ for Renewable and \\ Sustainable Energy Studies (CRSES), Department of Industrial Engineering, Stellenbosch University, Stellenbosch, \\ South Africa; ${ }^{9}$ Sustainable Energy Systems, Engineering and Computer Science, Victoria University of Wellington, \\ Kelburn, New Zealand
}

\begin{abstract}
There is an emerging scholarship that criticises the conceptualisation of urban informality from a deficit view and emphasises that informality constitutes a way of life, a practice in its own right. We argue that energy is part of the informal way of life and that energy transitions need to take into account the specificities of urban informality when used for policy. Acknowledging energy practices is necessary to improve the justice of energy transitions, including the urban poor in energy transitions without denying the legitimacy of slum dwellers' ways of life. In this paper, we analyse energy governance in informal urban settlements as implemented by national governments, municipalities and non-governmental organisations, with case studies from Sub-Saharan Africa. We develop a policy analysis framework that assesses (1) the practices of problem definition; (2) the creation of policy options and strategy; (3) the mix of capacities mobilised; and (4) the type of instruments used. The framework is applied to three case studies of energy policies in informal settlements in Kenya, South Africa and Uganda. Results show a strong preference for regulation and technological fixes and do not create capacity to acknowledge and integrate the specific challenges of urban informality and informal ways of life in energy policy, hence falling short of addressing social justice in energy transitions.
\end{abstract}

\section{ARTICLE HISTORY}

Received 19 February 2020 Accepted 13 October 2020

\section{KEYWORDS}

Policy analysis; informal settlements; slums; energy poverty; policy implementation; infrastructure

\section{Introduction}

Urban informality has been understood as opposite to the formal, regulated, planned city and as something defined by deficit rather than a reality in its own right. There is an emerging scholarship that aims at challenging these definitions, by shedding light on informality as a way of life (Roy and AlSayyad 2004; AlSayyad 2004), which necessitates its own epistemology (Roy 2005) and as a type of "mobile infrastructure" (McFarlane and Vasudevan 2014). Urban informality is thus recast as an active way of being in the city, which is often constitutive of the city itself. The shift in perspective from 
deficit to way of life has implications for how social justice is understood. Is justice a matter of recognising the legitimacy of informal ways of life or overcoming the marginalisation of the urban poor? Does the inclusion of slum dwellers in energy transition policies necessarily impose a way of life that denies the legitimacy of informal dwelling? How can a balance be reached between procedural justice (which includes recognition of informal ways of life) and fair outcomes (giving the urban poor access to modern and renewable energy)?

We argue that while scholarship on slums has evolved in its conceptualisation of urban informality, urban policy lags behind. The framings used to define the "slum problem" in policy realms do not see urban informality in its own right, but only as far as it conforms with the dominant scripts of urban development (McFarlane and Vasudevan 2014). Referring to sanitation projects, McFarlane and Vasudevan argue that the stories that are mobilised in policy are "not the messy, excremental politics of daily grind, but the shining and seemingly harmless success stories that fit with elite aspirations to build more entrepreneurial cities" (2014, 261).

This paper contributes to this emerging scholarship by exploring how energy transition policies conceptualise and engage with urban informality. The deficit paradigm defines slums as lacking access to modern energy, such as electricity. Similarly to sanitation, energy policy in slums reflects the preoccupation with sustainability and climate change mitigation of the global elite, producing the "unsustainable urban poor" (Kovacic 2018). The use of fuels such as charcoal and paraffin are interpreted as evidence of the backwardness of energy consumption patterns in slums. An example of this framing is statistics that report that Africa accounts for one-fifth of the world's population but for less than $4 \%$ of global electricity consumption (The Economist 2019). If urban informality is seen as a way of life, the use of paraffin and charcoal should rather be understood as affording flexibility in repurposing cooking stoves (Kovacic et al. 2019). In the latter case, energy is part of the informal way of life. Energy transitions need to take into account how changes in fuel type will impact urban informality lest they reproduce dynamics of social exclusion. With regard to justice, energy transitions face the challenge of striking a balance between respecting informal ways of life and including the urban poor in urban energy infrastructure.

The critical view of urban informality reveals a knowledge gap in the energy transitions literature with regard to the different ways of life afforded by different energy sources. Giving access to modern and sustainable types of energy may disrupt those informal ways of life that thrive on the use of flexible, if unsustainable, energy sources. As a result, energy transitions run the risk of being unjust transitions. As Bailey and Darkal (2018) argue, this risk is due to a misalignment between the energy justice and social justice perspectives. Energy justice focuses on the promotion of access to safe, affordable and sustainable energy. In the context of energy policy, we will show how energy justice translates in a focus on technological solutions. Social justice, in turn, pays attention to inclusiveness, decision making and procedural matters. Energy policy must therefore be analysed not just with regard to the types of energy it promotes, but also with regard to how the needs of the urban poor are accounted for in problem framing and policy implementation. Social justice scholars also argue that the focus on infrastructural deficits "overemphasize[s] physical and infrastructural solutions at the expense of social, economic and political reforms" (Shi et al. 2016, 134) needed to grant equity and justice. Conceptualising urban informality and informal energy practices as a way of life helps shed light over the impacts of energy transitions policies on social justice in marginalised communities and contributes to a better understanding of the challenges of just sustainability.

This paper asks: How do energy transition framings impact slum policies? Which aspects of justice are mobilised by energy transition framings and which are left behind? We respond to these questions by developing and testing a framework of policy analysis which assesses the framing decisions and policy tools through which governance is practiced, including problem definition, policy strategy, capacities and instruments used. Our interest is two-fold: (1) we analyse the problem-solution framings that regard energy use in slums and enquire to what extent these framings are compatible with informal ways of life, and (2) we assess policy implementation by observing the capacities and 
instruments mobilised by energy transition policy framings with attention to how procedural and social justice are affected. By taking into consideration both the framings and the implementation of policy, we aim to enquire whether governing capacity is built towards sustainable and just transitions.

We test this analytical framework using three case studies of energy policy: a national level policy in Kenya; an informal settlement upgrading initiative in South Africa driven by a collaboration between a local municipality and an NGO; and a technological innovation project in Uganda implemented through a collaboration between a local municipality and the local university. The three case studies provide insights on the perils of technology-based solutions for the promotion of social justice in energy transitions.

\section{Policy analysis framework}

We propose an analytical framework for informal settlement policy based on four criteria: (1) problem definition; (2) policy options and strategies; (3) capacity mix; and (4) instrument mix. The four categories describe the practice of informal settlement governance without ascribing a sequential logic to these practices. Following Colebatch, we argue that policy processes do "not begin with 'the government' identifying a 'problem' and looking for a solution" $(2005,20)$. Policies are better understood as the result of "a longer pattern of interaction between a range of organisational forms, inside government, outside it and in between, in which participants [seek] to structure action in various ways, frequently invoking state authority" (Ibid: 20). We use the term "governance" to describe "the participation of non-governmental actors in public policy-making and delivery" (Bache and Flinders 2004, 35). In the case studies we analyse, both NGOs and university-based research groups partake in the governance of informal settlements.

The first criterion is the framing or definition of the problem. The "problem" is not a given fact to which governance needs to reply but is part of the practice of governing. Colebatch (2005) argues that constructing a problem is part of the instrumental model of governing, which mobilises problems as a means to invoke action. In the case of informal settlements, "problems" are usually defined following (1) the logic of space; (2) the ideology of aesthetics; and (3) the market logic (Roy 2005; Scott 1998). The logic of space frames informality as embodying the marginalisation and segregation of the poor in specific neighbourhoods. The ideology of aesthetics reduces informality to the precarious material conditions of informal settlements, such as inadequate housing, lack of water, sewerage and electricity. The market logic frames informality as the problem of being excluded from the market. The logic of space and the ideology of aesthetics have been identified as critical also in the environmental justice literature, which denounces how marginalised communities have suffered from greater exposure to waste sites, incinerators, refineries and transportation infrastructures (Martinez-Alier et al. 2014).

In our case studies, the problems mobilised have to do with the unsustainable sourcing of energy, the lack of access to electricity, and the use of "dirty" energy. In all three cases, urban slums pose specific challenges to the problem of unsustainable energy use, which are related to the broader social and institutional conditions of informality. Because of lack of connection to the electricity grid, other forms of energy are widely used - including polluting and unhealthy sources such as paraffin and coal. Due to economic limitations and proximity constraints, slum dwellers cannot always afford modern energy sources. The limited presence of public agencies, including utilities, derives in a difficulty in monitoring energy use and collecting revenues.

We thus stress that the "problem" of energy in slums is not just a technical problem, but also a social and institutional one, which alerts to a lack of distributive and procedural justice. Unsustainable energy use does not refer only to what is environmentally harmful, but also to what is socially and economically inequitable. Problem definition is a particularly value-laden and power-laden step in the policy process, which raises questions such as: Who defines what the problem is? Whom does the problem affect, include and leave out? and What is at stake? Marres $(2007,2005)$ has argued that 
issue definition should be a democratic process because issues define which type of public is involved. For this reason, the achievement of social justice necessitates that the needs of slum dwellers be included in the problem definition.

The second criterion, identification of policy options and strategies, is also part of the instrumental conceptualisation of governance, which provides "an explanation of present arrangements and a justification for change" (Colebatch 2005, 20). As Bacchi (2009) has argued, policy can be understood as the exercise of defining solutions to a "problem". She stresses that in the very framing of an issue as a problem, a specific course of action is called for and specific power relations are legitimised. The three narratives, used to define the problem of informality, carry with them an expected solution which narrows the policy option space. The logic of space is conveyed to justify relocation programmes. Aesthetic considerations are mobilised in upgrading programmes, that improve housing and provide services such as water and sewerage, electricity, health care centres, waste collection, etc. The market logic solves informality by giving the urban poor house titles, access to credit and other means that formalise informal transactions. In all three narratives, the urban poor are rendered as powerless and in need of legitimation, guidance and permission to participate.

With the third criterion on capacity mix, we turn our analysis to the practices of policy making. Different governance levels may present different practical challenges. A policy-maker at the municipal level may be faced with emergency-management linked to fire and epidemic outbreaks in slums, while policy-makers sitting at the UN may be faced with the challenge of dealing with overloads of reports, information, meetings and demands. Even though the problem-solution framing may give the impression that informal settlements are governed through planning, day-to-day practice shows that often informal settlement governance is more a matter of coping with emergencies and bureaucracy.

Policy design is crucial to improving justice. The social justice literature stresses the importance of including justice considerations from the outset in design and urban planning. Shi et al. (2016) explain how climate adaptation is realised through large-scale infrastructure projects and is oblivious of social justice goals. Anguelovski (2016) argues that green urban areas that supposedly improve living conditions can turn into locally unwanted land uses if they reproduce unjust dynamics of gentrification and displacement of the urban poor. For this reason, we take into account a wide range of capacities, that broaden the analysis of policy-making to collaboration and an extended advisory community.

In order to account for the crucial role that practice plays in the policy process and in the pursuit of procedural justice, we refer to a series of capacities that are closely related to informal settlement policy:

(1) Legal capacity: This capacity refers not so much to the institution or legal framework that has responsibility or grants the mandate to act, but to persons or institutions that have the capacity to establish mandates and responsibilities. Thus, informal settlement policy depends not only on the creation of e.g. new building codes, but on the capacity to work across governance scales, so as to avoid mandate voids between national level regulation and municipal mandates.

(2) Implementation capacity: The capacity to catalyse action. Implementation capacity may entail creating a dedicated office within the municipal or national government to deal with informal settlements, rather than assuming that policies will be implemented everywhere. Implementation should rely also on the involvement of slum dwellers, as a means of promoting social justice.

(3) Resourcing capacity: The capacity to raise and absorb resources such as financial, human and information technology. The federal government may have the capacity to raise financial resources, but funds need to be matched by the capacity of municipal governments to absorb these resources and mobilise them towards the required ends. 
(4) Advisory capacity: The capacity to generate, harvest and communicate relevant locally-specific knowledge. Advisory capacity is crucial to the governance of urban informality because in this context the knowledge that is applied to urban planning more broadly fails to attend the specific needs of slums. Knowledge is broadly used to include scientific knowledge, practitioner knowledge and local knowledge from slum dwellers, which opens the way for more inclusive and equitable policy implementation.

(i) The need for locally produced scientific knowledge stems from the fact that often researchers and institutions from the Global North are preferred over local universities. The preference for "First World knowledge" not only reproduces the problem of colonisation of knowledge, but also leads to the use of models and theories based on the observation of First World cities (such the Chicago school of urban sociology or the Los Angeles school of postmodern geography), which fail to explain Third World phenomena, such as urban informality (Roy 2005).

(ii) Practitioner knowledge refers to the practical knowledge that local municipalities accumulate about the successes and failures of urban informality governance and policy implementation.

(iii) Local knowledge refers to the involvement of slum dwellers and local communities in policy design, both as a means improve democratic accountability and social justice, and as a means to make sure that policy benefits the people, thus strengthening the alignment of public values and local needs.

Collaborative capac vity: The capacity to build partnerships and create opportunities for crosssector learning and innovation. Collaborative capacity may also refer to the ability to bring about cross-sectoral collaboration and build bridges between mandates, so as to tackle the issue of mandate overlaps.

Finally, our fourth criterion on instrument mix refers to the instruments through which policies are implemented. We argue that attention to instruments is crucial to reach a deeper understanding of the practical challenge of translating a policy strategy into implementable action. This translation often entails adapting one's goals to the means available. Instruments are thus of interest in this framework not because of the actions they lead to, but because they raise awareness about the difficulty of implementing, as opposed to designing, policy. The analysis of instruments may also point to the challenge of mobilising notions of social justice in practice.

The instruments used in the governance of urban informality include (Roy and AlSayyad 2004; Birkmann et al. 2010):

(1) fiscal instruments, such as taxes, subsidies and budget allocation to specific industries;

(2) technology and infrastructure;

(3) capacity building and training, such as business incubation, policy briefs and awareness campaigns;

(4) regulatory instruments, such as product standardisation, reporting requirements, monitoring and land titling;

(5) communication tools, such as translation and, non-technical jargon (using a language and level that participants can understand); and

(6) coordination structures, such as networks, platforms for collaboration and cross-sectoral collaborations.

Some instruments are more institutionalised, such as fiscal and regulatory instruments, while others may arise in response to specific needs at the local level and be driven by social justice considerations, such as the need for translation to improve procedural justice when local representatives 
Table 1. Policy analysis framework.

\begin{tabular}{|c|c|c|c|}
\hline Problem framing & Policy options/strategies & Capacity mix & Instrument mix \\
\hline \multirow[t]{2}{*}{$\begin{array}{l}\text { Inadequate housing, lack of } \\
\text { property titles }\end{array}$} & Titling & $\begin{array}{l}\text { Legal capacity: who has the } \\
\text { mandate? }\end{array}$ & $\begin{array}{l}\text { Fiscal: taxes, subsidies, } \\
\text { budget allocation }\end{array}$ \\
\hline & Building codes & $\begin{array}{l}\text { Implementation capacity: } \\
\text { who can catalyse action? }\end{array}$ & $\begin{array}{l}\text { Technology: infrastructures, } \\
\text { innovations }\end{array}$ \\
\hline $\begin{array}{l}\text { Lack of, or insufficient, basic } \\
\text { resources (water, electricity, } \\
\text { food etc.) }\end{array}$ & $\begin{array}{l}\text { Infrastructure (water taps, } \\
\text { grid connection) and } \\
\text { resources (water, } \\
\text { electricity) provision }\end{array}$ & $\begin{array}{l}\text { Resourcing capacity: who } \\
\text { can mobilise financial, } \\
\text { human resources and } \\
\text { information? }\end{array}$ & $\begin{array}{l}\text { Capacity building and training: } \\
\text { business incubation, policy } \\
\text { briefs, awareness campaigns }\end{array}$ \\
\hline \multirow{2}{*}{$\begin{array}{l}\text { Lack of, or insufficient basic } \\
\text { services (schools, health } \\
\text { sanitation, sewerage, } \\
\text { information, transportation, } \\
\text { etc.) }\end{array}$} & $\begin{array}{l}\text { Infrastructure and services } \\
\text { provision }\end{array}$ & $\begin{array}{l}\text { Advisory capacity: who } \\
\text { informs policy? }\end{array}$ & $\begin{array}{l}\text { Regulatory instruments: product } \\
\text { standardisation, reporting } \\
\text { requirements, land titles }\end{array}$ \\
\hline & & $\begin{array}{l}\text { Collaborative capacity: who } \\
\text { can build partnerships } \\
\text { and establish networks? }\end{array}$ & $\begin{array}{l}\text { Communication: language and } \\
\text { level that participants can } \\
\text { understand } \\
\text { Coordination structures: } \\
\text { networks, platforms, for } \\
\text { collaboration and cross- } \\
\text { sectoral collaborations }\end{array}$ \\
\hline
\end{tabular}

speak different dialects or languages. Although new instruments can be created, time and resource constraints may restrict governance practices to what has been done before and to what can be measured and reported according to accountability standards.

Table 1 summarises the four categories through which we assess informal settlement governance. We argue that problem definition, policy strategy, capacity mix and instrument mix are all means through which urban informality is governed.

In terms of promoting just energy transitions, a crucial part of policy implementation is also dealing with the power relations and institutions that guide practical action. We refer to institutions as the rules used to organise "all forms of repetitive and structured interactions including those within families, neighbourhoods, markets, firms, sports leagues, churches, private associations, and governments at all scales" (Ostrom 2005, 3). Institutions embody power structures and govern the practice of policy implementation. The choice of instruments may thus perpetuate mechanisms of social exclusion when, for instance, English is used as the "common" language, rather than local dialects.

\section{Case studies}

We apply the policy analysis framework to three case studies of energy policy initiatives in Kenya, South Africa and Uganda. The focus on informal settlements raises the question of whether energy transitions are conducive to social justice, and what type of balance is reached between acknowledging informal ways of life and integrating slum dwellers in urban energy infrastructure. The three policies refer to different levels of governance, so that the combined study of these three experiences makes it possible to gain insights in the challenge of energy transitions in different contexts.

The three case studies are not representative of the policies of either country. National level policies are implemented in all three countries and a wide range of small scale initiatives led by local governments, NGOs and research centres can be found in all three countries. The case studies are just examples of energy transition policies in informal settlement in Sub-Saharan Africa, based on the project "Co-designing energy communities with energy poor women in urban areas: case studies in Kenya, Uganda and South Africa" funded under the Leading Integrated Research for Agenda (LIRA) 2063 in Africa programme. 


\section{Charcoal ban in Kenya}

In order to control deforestation and unauthorised charcoal production, the Kenyan government implemented temporary bans on charcoal production. In 2018, a 3-month ban on logging was enforced (Gumbihi 2018). This policy is not directed at informal settlements but closely affects informal settlement dwellers. Charcoal is used for cooking and heating among lower income households and is the second most used fuel in informal settlements in Nairobi, after paraffin (Kovacic et al. 2019). As a result, the ban of charcoal creates a problem for the urban poor with implications for social justice. The popularity of charcoal is due to a variety of factors including cost, availability, ease of use and ease of access. Cost means both that charcoal is bought when it is cheaper than other fuels and that it does not require regular payments, which may be incompatible with casual jobs.

Temporary bans on charcoal are driven by environmental concerns regarding the sourcing of trees for charcoal production. Critics, however, insist that a ban does not induce producers to adopt more sustainable charcoal production practices and is punitive towards those that have adopted sustainable practices (Gumbihi 2018; Njenga 2018).

The 2018 ban on logging drove the prices of charcoal up. Poor urban dwellers, however, cannot always afford other types of energy. An increase in the price of charcoal did not necessarily lead people to switch to a different fuel, because other fuels may not be readily available and may require different cooking or heating appliances. Moreover, many informal dwellers rely on food vending for their livelihoods and a higher price of charcoal makes their business economically unviable (Gumbihi 2018). The ban creates a higher risk of energy poverty.

Because of the lack of alternatives to charcoal and the temporary nature of the ban, this policy renders the existing charcoal market informal. In the case of the Mathare informal settlement in Nairobi, saw dust production emerged as a new informal business and an alternative to charcoal (Ambole et al. 2019). The production of charcoal is made illegal, not necessarily its use. Therefore, the commercialisation of charcoal in informal settlements is left in legal limbo between legality and illegality, regulation and lack of regulation, which is associated with informality. The ban exacerbates urban informality by making previously legal activities informal.

Because this is a high-level policy implemented at the national level it is not adapted to the local scale. The temporality of the ban leads some households to hold off on, for instance, water heating during the ban (Gumbihi 2018). These coping strategies can have a negative spill over effect on hygiene and health.

\section{Ishack in Enkanini}

The second case study is the upgrading programme promoted by iShack, a local NGO in the Enkanini informal settlement, Stellenbosch, South Africa. The upgrading programme was conceived and coordinated by the iShack project, funded by the Bill and Melinda Gates Foundation and implemented with the support of Stellenbosch Municipality (Kovacic et al. 2016; Smit et al. 2019). The project started in 2012 with a specific focus on the Enkanini informal settlement and the NGO has, since 2018, expanded to other informal settlements in Stellenbosch. This project is an interesting case study because it creates a dialogue between different levels of governance involving an international foundation, a local NGO and the local government. This initiative promotes the transition towards renewable energies and the municipality of Stellenbosch has received a prize for its efforts in promoting renewable energies.

The iShack project was initially designed to "improve shacks" by providing better insulation and cheap rooftop solar panels for single house use (Keller 2012). The project later specialised in the provision of solar panels and maintenance services. Solar panels are designed so that they can be produced locally and cheaply. The panels are connected to a car battery, which provides enough electricity for lighting and charging of small appliances such as cell phones. Solar panels are 
provided to households for free and households are required to pay a monthly fee of 150 South African Rand (approximately 10USD) for maintenance services. The financial viability of the project is guaranteed through the funding received by the Bill and Melinda Gates Foundation, which is used to build the solar panels. The maintenance fee is kept as low as possible in order not to act as an entry barrier for poor households. However, the requirement of monthly payments imposes a burden on households that do not have a regular income and that rely on casual jobs, effectively excluding the poorest families from the project and/or making participation temporary.

The iShack project faced a legitimacy crisis in 2015. Enkanini's residents associated connection to the electric grid with formal recognition of the settlement by the municipality. As the municipality endorsed the iShack project, residents believed that the settlement was given solar panels as a token and instead of, formal recognition. In July 2015, the iShack facilities in Enkanini were vandalised (Kovacic et al. 2016). This episode led to a change in narrative and the iShack programme is now introduced in new informal settlements as a temporary solution, put in place while the settlement is waiting to be connected to the electric grid. This way, residents are assured that their demands are taken into account. The incident illustrates the challenge of balancing the respect for informal ways of life and the inclusion of informal settlements in the transition towards renewable energies.

The conflict surrounding the iShack project in 2015 can be seen both as a communication failure in the short term, because Enkanini's residents misunderstood the iShack project as the response of the municipality to their demand to be connected to the electric grid and as a legitimisation success in the long term, because the success of the iShack project and the visibility it gained through international funding gave a voice to Enkanini's residents and their hitherto unheard demands. The case study suggests that time dynamics are crucial to understanding the success or failure of policies towards social justice.

\section{Briquettes in Kasubi-Kawaala}

The third case study is an example of a research-driven project carried out by a research lab of the University of Kampala in collaboration with the Kampala Capital City Authority, Uganda. The project targeted primarily the informal settlement of Kasubi-Kawaala and provided training and equipment for the production of briquettes, an alternative to charcoal produced from recycled organic waste, which can be used in the same way as charcoal but is less toxic. Briquettes are locally produced and sold in the settlement. The project thus aims to promote a business opportunity for the local community. Briquettes also provide an interesting means of disposing of organic waste, thus reducing the hazards caused by the improper dumping of waste in public spaces.

The project stemmed from health concerns linked to the high reliance on charcoal for cooking and water heating among urban households. The burning of charcoal is linked to a variety of respiratory diseases, eye infections and the aggravation of illnesses such as tuberculosis. The preference for charcoal is determined by cost, ease of use, access and, importantly, cultural preferences. As a consequence, the project aimed at providing both an alternative to charcoal and at knowledge transfer and awareness raising. The similarity of briquettes to charcoal, takes into account cultural preferences and the practical need to provide a fuel that can be used on existing stoves, respecting the informal way of life of the dwellers.

The interest and drawback of this project is that it requires considerable training. On one hand, training signals the intention to move beyond a technological fix. The project aims at creating knowledge and raising awareness. On the other hand, the training requirements lead to long implementation times and to the low transferability of skills to other residents. Briquettes are, in practice, sold to the families of those involved in the project, both because the strong preference for charcoal limits interest in the project and because of the limited production capacity of the pilot installations. The project is thus difficult to scale up beyond the pilot level, as it depends on training by university students and researchers and on research funding for the provision of equipment. 
Unlike the iShack project, this is a local scale only project. Funding, training and legal support rely on local capacity. This case study reveals a trade-off between context adaptation and replicability. The briquettes initiative is well adapted to cultural preferences and locally available resources (organic waste), but it does not have the capacity to scale up. We suggest that this trade-off is recurrent in the governance of informal settlements, because of the diversity and specificity of challenges that characterise urban informality.

\section{Results of the policy analysis}

Returning to the question of how energy transition framings impact energy policies in slums, the three case studies are analysed according to the framework developed in section 2. The implications of energy transition framings in slum policy are assessed both with regard to (1) how the problem is defined; and (2) the associated policy options or strategy mobilised. With an eye on how framings impact policy implementation and consequently social justice, we assess (3) the capacities mobilised and the capacities missing from each policy project; and (4) the instruments used to implement the policy options. The results of the analysis can be seen in Table 2.

The problem definitions reflect the understanding of informal settlements through logics that rehearse technocratic management.

(1) The charcoal ban enacts the market logic: a ban is supposed to lead economic agents to switch to other fuel sources available on the market. The challenge is therefore one of steering economic agents through market regulation. As discussed above, this measure fails to steer those that do not have access to the formal market and leads to the creation of informal markets, such as the local sawdust production in Mathare, Nairobi. The market logic reinforces the representation of slum dwellers through failure - the failure to act as rational economic agents and the failure to participate in the market mechanism. The reliance on the market mechanism reproduces the distributive and access inequalities denounced by the early social justice literature (Rawls 1971).

(2) The iShack project mobilises the ideology of aesthetics. The challenge is defined as the basic infrastructure and resource deficit of electric grid and electricity. In this case, the problem of lack of services is reduced to a challenge that can be overcome with the technological solution of providing solar panels. As discussed by Kovacic et al. (2016), this problem definition ignores the symbolic function of the claim for electricity and service provision as a means to achieve the official recognition of the settlement. The ideology of aesthetics also ignores the larger mechanisms through which informality is produced, by acting on the physical effects rather than on the dynamics of exclusion and discrimination. The challenge would be better defined as a legitimacy deficit: the solution envisioned does not take into account the aspirations of informal settlement dwellers. Energy justice, in the sense of access to modern and renewable energy, is given priority over social justice.

(3) The briquettes initiative also rehearses the ideology of aesthetics, by focusing on the type of fuels used in the Kasubi-Kawaala informal settlement and couples it with a diagnosis of information deficit. Informal urban dwellers use charcoal because they do not know of the health hazards associated with charcoal burning. The solution is to inform people, raise awareness about health hazards and to provide training so that briquettes can be produced locally. In this case, the informal way of life is taken into account but reduced to a technological solution. The information deficit asserts the need for expert knowledge and education, rendering the urban poor as ignorant subjects. The information deficit resonates with the market logic, in as far as those that fail to act as rational agents are educated in the rationality expected of economic agents. Trained subjects are then expected to sustain the demand for briquettes and create a new market. 
Table 2. Results of the policy analysis.

\begin{tabular}{|c|c|c|c|c|}
\hline Case study & Problem framing & $\begin{array}{l}\text { Policy options/ } \\
\text { strategies }\end{array}$ & Capacity mix & Instrument mix \\
\hline \multirow[t]{4}{*}{$\begin{array}{l}\text { Charcoal ban } \\
\text { in Kenya }\end{array}$} & \multirow[t]{4}{*}{$\begin{array}{l}\text { Deforestation and } \\
\text { unsustainable } \\
\text { charcoal production }\end{array}$} & Ban charcoal & $\begin{array}{l}\text { Legal capacity: the government } \\
\text { has the capacity to enforce the } \\
\text { ban }\end{array}$ & \multirow[t]{4}{*}{$\begin{array}{l}\text { Regulatory instruments: legal } \\
\text { ban }\end{array}$} \\
\hline & & $\begin{array}{l}\text { Mandate void } \\
\text { with regard to } \\
\text { informal } \\
\text { settlements }\end{array}$ & $\begin{array}{l}\text { Implementation capacity: } \\
\text { limited implementation } \\
\text { capacity as charcoal } \\
\text { production is made illegal and } \\
\text { its commercialisation becomes } \\
\text { informal }\end{array}$ & \\
\hline & & & $\begin{array}{l}\text { Advisory capacity: the policy is } \\
\text { informed prdominantly by } \\
\text { environmental concerns }\end{array}$ & \\
\hline & & & $\begin{array}{l}\text { Collaborative capacity: the policy } \\
\text { is created in a "silo" and spill } \\
\text { over effects on energy poverty } \\
\text { are not considered }\end{array}$ & \\
\hline \multirow[t]{5}{*}{$\begin{array}{l}\text { iShack in } \\
\text { Enkanini }\end{array}$} & \multirow[t]{5}{*}{$\begin{array}{l}\text { Lack of electricity in the } \\
\text { informal settlement } \\
\text { (basic infrastructure } \\
\text { and resource deficit) }\end{array}$} & \multirow[t]{5}{*}{$\begin{array}{l}\text { Provision of } \\
\text { rooftop solar } \\
\text { panels }\end{array}$} & $\begin{array}{l}\text { Legal capacity: there is a } \\
\text { mandate void, the iShack NGO } \\
\text { has the capacity to install solar } \\
\text { panels but not to authorise the } \\
\text { connection of the settlement } \\
\text { to the electric grid }\end{array}$ & $\begin{array}{l}\text { Fiscal: funding for the } \\
\text { construction of solar panels }\end{array}$ \\
\hline & & & $\begin{array}{l}\text { Implementation capacity: the } \\
\text { iShack NGO has the capacity to } \\
\text { catalyse action }\end{array}$ & Technology: solar panels \\
\hline & & & $\begin{array}{l}\text { Resourcing capacity: the Bill and } \\
\text { Melinda Gates Foundation } \\
\text { provides the financial } \\
\text { resources }\end{array}$ & $\begin{array}{l}\text { Coordination structures: } \\
\text { NGO-local government } \\
\text { collaboration }\end{array}$ \\
\hline & & & $\begin{array}{l}\text { Advisory capacity: residents of } \\
\text { the informal settlements are } \\
\text { only partially able to inform } \\
\text { policy }\end{array}$ & \\
\hline & & & $\begin{array}{l}\text { Collaborative capacity: the } \\
\text { iShack NGO establishes a link } \\
\text { between the municipality and } \\
\text { the residents of Enkanini }\end{array}$ & \\
\hline \multirow[t]{2}{*}{$\begin{array}{l}\text { Briquettes in } \\
\text { Kasubi- } \\
\text { Kawaala }\end{array}$} & $\begin{array}{l}\text { Health problems } \\
\text { associated with } \\
\text { charcoal consumption }\end{array}$ & $\begin{array}{l}\text { Local production } \\
\text { of briquettes } \\
\text { from organic } \\
\text { waste }\end{array}$ & $\begin{array}{l}\text { Implementation capacity: } \\
\text { limited implementation } \\
\text { capacity, briquettes are used } \\
\text { only by those involved in the } \\
\text { project }\end{array}$ & \multirow[t]{2}{*}{$\begin{array}{l}\text { Capacity building and } \\
\text { training: training in the } \\
\text { production of briquettes } \\
\text { and raising awareness } \\
\text { about the health problems } \\
\text { of burning charcoal } \\
\text { Technology: briquettes }\end{array}$} \\
\hline & Information deficit & $\begin{array}{l}\text { Training and } \\
\text { awareness } \\
\text { raising }\end{array}$ & $\begin{array}{l}\text { Advisory capacity: the local } \\
\text { university provides the } \\
\text { expertise and technical } \\
\text { training }\end{array}$ & \\
\hline
\end{tabular}

The problem framing of the cases analysed invites technological solutions and rehearses the representation of informal dwellers as failing (to participate in the market, to access the necessary knowledge). The policy options and strategies derived from these framings are based on regulation (ban), material upgrading (solar panels and briquettes) and education (briquette production training). This approach aims at 'repairing deficits' and falls short of recognising how informality is produced by the failure of formal planning to account for the multiple functions of a city, for the role of practical and local knowledge (Scott 1998). Moreover, the technocratic framing reproduces the separation between physical-infrastructural and social-institutional interventions, which limits efforts to advance equitable urban planning (Shi et al. 2016). 
Different policy options rely on different capacities: the charcoal ban necessitates legal capacity, the iShack project necessitates implementation and resourcing capacity, and the briquettes project necessitates advisory capacity. The analysis also reveals that the lack of capacities is critical in explaining the shortcomings of each policy and the narrow focus of justice as the provision of technology and infrastructure. Lack of capacities may be due either to missing capacities or to the failure to mobilise existing capacities.

(1) With regard to the charcoal ban, the policy relies on regulatory instruments and legal capacity. While the consistency between capacity and instrument is clear, the policy fails to promote more sustainable logging practices and is heavily criticised for its impact on the urban poor. The effect of the charcoal ban on informal settlements is that the lack of legal and healthy alternatives to charcoal aggravates energy poverty. The policy exemplifies how social injustice is created in the pursuit of sustainability.

The charcoal ban relies on a top-down model of decision-making and on an authoritarian mobilisation of power. The authoritarian mode of intervention, combined with the restriction of government to the role of "market regulator" can be linked to the creation of informality itself.

(1) In the case of the iShack project, there is a clear match between implementation capacity and the installation of solar panels as well as resourcing capacity and the provision of funding. Nevertheless, the project initially failed to take into account the demands of Enkanini's residents, for legal recognition of the settlement. The availability of a techno-fix diverted attention from the legitimacy of the project. The conflict also reveals a gap in legal capacity. The NGO does not have the mandate to authorise the connection of the Enkanini informal settlement to the electric grid. The conflict with the Enkanini community was exacerbated by the failure to mobilise advisory capacity and involve residents in the decision making process, revealing a gap in building capacity towards social justice. The lack of advisory capacity can be explained with regard to the technocratic orientation of the project, which focused on the use of technology and the mobilisation of funding.

The case study is also an interesting example of the long-term impacts of policy interventions. The success of the iShack project in attracting funding from an international NGO, gave visibility to both the project and the community. As a result, the iShack NGO acquired collaborative capacity and was able to establish a link between the residents of Enkanini and the local municipality. The apparent ambivalent results of the iShack project as a communication failure and a legitimacy success can be explained as a failure to mobilise advisory capacity at the onset of the project and as the successful use of collaborative capacity that enabled communication between the residents and the municipality in the long-run. This case study also alerts us to the need of considering long-term effects in the study of social justice. A policy hailed from a narrow energy justice perspective aimed at providing solar panels, evolved to include the political concerns of slum dwellers improving on both social and procedural justice.

(1) The briquettes project in Kasubi-Kawaala relies on the coupling of advisory capacity (technical knowledge on briquettes) with capacity building instruments (training in the production of briquettes). The project also successfully expands its advisory capacity to take cultural preferences into account, thus relating to local knowledge. As a consequence, the project did not create a conflict with the local community as in the previous case. However, this research-driven initiative does not have the legal and resourcing capacity to ensure the continued existence of the project overtime. Credibility is affected not by the viability of the project, but by its self-contained nature. 
The third case study is an example of expert-driven process, which relies on the authority of technical knowledge and expertise but does not sufficiently engage with power structures and therefore falls short of promoting social justice and providing alternative models of governance. In an overview of informal settlement policies, Mukhija (2001) argues that unsustainable funding and nonreplicability are endemic problems in the governance of urban informality.

\section{Conclusion}

This paper set out to analyse (i) the work that energy transition framings do in slum policies and (ii) which aspects of social justice are mobilised and which are left behind. The joint analysis of energy transition framings and social justice makes it possible to build a better understanding of the challenges of achieving just sustainability. In the context of slums, the challenge is aggravated by the difficulty in finding a balance between promoting sustainable energy and infrastructure while acknowledging the informal way of life and the needs of the urban poor.

Energy transition framings impact slum policies by promoting the use of modern, sustainable and renewable energy sources, which becomes an all-encompassing strategy to deal with the many problems associated with poor access to energy. The solutions put in place in each case study are different, but they all focus on the transition from unsustainable to sustainable energy, from polluting to clean energy, from traditional to modern energy. In other words, there is a strong drive to technological solutionism, in which the change in type of energy takes centre stage. This ignores the associated social and institutional hurdles of urban informality and the way of life that nonmodern fuels enable.

With regard to policy implementation, the capacities mobilised are mostly geared towards technocratic management, which relies on funding and legal instruments and is based on scientific and expert knowledge. There is no space in any of the projects for the development of advisory capacity from slum communities, and for a more social justice-oriented policy design. A deeper understanding of how energy constitutes the informal way of life finds no resonance and no audience in policy realms. The policies and interventions analysed may well have been designed for formal urban areas. Urban informality and its specific needs for social justice do not inform policy.

We argue that the disregard for the informal ways of life is in part a consequence of the institutional culture that favours actionable policy and of the practical challenge of designing instruments. Availability of instruments tends to define how policies are put into practice, rather than the other way around in which policy needs lead to the design of new instruments. The important contributions of scholars that theorise informality as a way of life do not readily translate into policy instruments. The knowledge needed to define a problem is not the same as the knowledge needed to solve that problem. As has been long acknowledge in the planning literature, "wicked problems" (Rittel and Webber 1973) decouple understanding from ability to act. The decoupling of understanding and action poses a problem to the instrumental model of governing, which justifies its legitimacy based on its capacity to do something about problems, not just identify problems.

We thus argue that energy transitions framings deepen the instrumental approach to governance because the preference for technological fixes responds to the institutional need of providing actionable policies such as installing solar panels and briquette production facilities. Actionable policy interventions can be monitored and measured, and therefore held accountable. In the SubSaharan context, with young democracies and a history of corruption, accountability and tangible policy interventions play an important role in legitimising governance. Policies that aim to honour the informal way of life could be imagined to favour measures such as setting up community gatherings, promoting legitimacy and local knowledge. These less tangible interventions, however, are more difficult to measure and monitor, and therefore fall short of responding to the institutional context in which slum policy is developed. 
Because of the institutional culture that favours tangible and accountable policy interventions, energy transition framings contribute to slum policy mostly, if not exclusively, in terms of setting technological solutions, providing access to modern and sustainable energy, and decreasing the environmental impact of energy infrastructure. This tendency tilts the balance between acknowledging informal ways of life and including the urban poor in the material upgrades of energy transitions towards the latter. In some cases, "including" the poor may actually mean "coercing" the poor to accepting material upgrades that do not respond to their needs. As a result, the capacity built towards energy transitions is left wanting when it comes to social justice. Coming back to Bailey and Darkal's (2018) distinction between energy justice and social justice, we observe that in slum policies, justice is reduced to the narrow view of energy justice interpreted as giving access to sustainable energy sources and infrastructure.

The dismissal of social justice considerations is further exacerbated by energy transition framings that define the common good from outside slum communities. Policies respond to the sustainability aims and commitments of the state, of municipalities and of academia. Yet, slum dwellers and informal communities are framed as being responsible for the failures that define their condition: failure to use modern and sustainable energy, failure to participate in the market and failure to adopt sustainable alternatives.

The energy transitions framing seems to rely on the action of urban dwellers whose ways of life are only minimally acknowledged. The charcoal ban does not provide alternative measures for the poorest parts of the population, who cannot afford or do not have access to more sustainable energy. The urban poor are especially vulnerable to the lack of alternatives because they cannot harvest different materials from their environment for their energy needs.

The solar panels initiative did not initially take into account what was at stake for the community in obtaining grid connection. Because of the conflict that ensued, the panels are currently utilised as an interim solution, "while you wait" ${ }^{\text {"1 }}$ for grid electricity. This development, however, no longer has the original aim of providing an alternative to grid electricity and may, or may not, support a longterm transition to renewable energy.

Lastly, the briquettes project is more sensitive to cultural preferences for charcoal. Unfortunately, the contribution of cultural preferences is restricted to informing the type of technological solution offered, without taking into account how being responsible for the production of briquettes may impact the lives of participants by requiring their working time. The briquettes project aims at educating people about the best energy use. This educational angle was met with some mistrust by the members of the community, who did not acknowledge for instance the link between charcoal smoke and the respiratory diseases they experienced (Kovacic et al. 2019). For this reason, the briquettes business was not reproduced in other slums and not even by residents of Kasubi-Kawaala, other than those involved in the project. While the project included both technological and social dimensions, the solution failed to gain acceptance from its "beneficiaries".

Energy policies do not take into account the role of energy in the informal way of life by design. The notable exception is the case of Enkanini, in which the role of the energy (in the form of connection to the electric grid) in the political struggle for recognition was acknowledged, albeit retroactively. The energy transitions framings do not help build capacity towards governance sensitive to informality. This result leads us to the question: energy transition framings generate capacity towards what? Energy transition framings are resolved by falling on available instruments and energy "problems" are reduced to technical problems.

The analysis of problem framings and solutions reveals that energy is reduced to a problem of lack of access and lack of information. There is little understanding of how energy is part of the informal way of life. As a result, energy transition framings may create tensions with social justice goals in informal urban settlements. Energy policy in this context requires a problem framing informed by the understanding of energy consumption patterns as a means through which the informal way of life unfolds. 


\section{Note}

1. https://www.ishackproject.co.za/

\section{Acknowledgements}

The authors would like to thank Siddhart Sareen, Patrik Oskarsson, Sören Becker, Kenneth Bo Nielsen, Jessica Verhei, and Luís Silva for their valuable suggestions on previous versions of the paper. The authors also acknowledge the constructive comments and suggestions of two anonymous reviewers and the journal's editor.

\section{Disclosure statement}

No potential conflict of interest was reported by the author(s).

\section{Funding}

This work was supported by the project Co-Dec (Co-Designing Energy Communities with energy poor women in urban areas: case studies in Kenya, Uganda and South Africa), funded by the LIRA2030 (Leading Integrated Research for Agenda 2030 in Africa) programme. Funding for the postdoctoral fellowship of the first author was provided by the Research Office of Stellenbosch University. Additional funding for policy work in Nairobi came from the Africa Climate Change Leadership (AfriCLP) program. AfriCLP is managed by University of Nairobi and is funded by the International Development Research Centre (IDRC).

\section{ORCID}

Zora Kovacic (iD http://orcid.org/0000-0002-0911-9273

Kareem Buyana (i) http://orcid.org/0000-0002-7710-3652

Shuaib Lwasa (iD) http://orcid.org/0000-0003-4312-2836

Alan Brent (D) http://orcid.org/0000-0003-3769-4512

\section{References}

AlSayyad, Nezar. 2004. "Urban Informality as a 'New' Way of Life." In Urban Informality: Transnational Persectives from the Middle East, Latin America, and South Asia, edited by Ananya Roy and Nezar AlSayyad, 7-30. Lanham: Lexington Books.

Ambole, Amollo, Josephine Kaviti Musango, Kareem Buyana, Madara Ogot, Christer Anditi, Baraka Mwau, Zora Kovacic, et al. 2019. "Mediating Household Energy Transitions Through Co-Design in Urban Kenya, Uganda and South Africa." Energy Research and Social Science 55 (May): 208-217. doi:10.1016/j.erss.2019.05.009.

Anguelovski, Isabelle. 2016. "From Toxic Sites to Parks as (Green) LULUs? New Challenges of Inequity, Privilege, Gentrification, and Exclusion for Urban Environmental Justice." Journal of Planning Literature 31 (1): 23-36. doi:10. $1177 / 0885412215610491$.

Bacchi, Carol. 2009. Analysing Policy: What's the Problem Represented to Be? Frenchs Forest: Pearson Australia.

Bache, Ian, and Matthew Flinders. 2004. "Multi-Level Governance and the Study of the British State." Public Policy and Administration 19 (1): 31-51. doi:10.1177/095207670401900103.

Bailey, lan, and Hoayda Darkal. 2018. "(Not) Talking About Justice: Justice Self-Recognition and the Integration of Energy and Environmental-Social Justice Into Renewable Energy Siting." Local Environment 23 (3): 335-351. doi:10.1080/ 13549839.2017.1418848.

Birkmann, Jörn, Matthias Garschagen, Frauke Kraas, and Nguyen Quang. 2010. "Adaptive Urban Governance: New Challenges for the Second Generation of Urban Adaptation Strategies to Climate Change." Sustainability Science 5 (2): 185-206. doi:10.1007/s11625-010-0111-3.

Colebatch, Hal K. 2005. "Policy Analysis, Policy Practice and Political Science." Australian Journal of Public Administration 64 (3): 14-23. doi:10.1111/j.1467-8500.2005.00448.x.

The Economist. 2019. "More than Half of Sub-Saharan Africans Lack Access to Electricity - Daily Chart." The Economist. https://www.economist.com/graphic-detail/2019/11/13/more-than-half-of-sub-saharan-africans-lack-access-toelectricity.

Gumbihi, Hudson. 2018. "Nairobi City Residents Feeling the Heat of Charcoal Ban." Standard Digital, April 6. https:// www.standardmedia.co.ke/business/article/2001275856/lifestyle-change-as-cost-of-charcoal-doubles-in-nairobi. 
Keller, Andreas. 2012. Conceptualising a Sustainable Energy Solution for in Situ Informal Settlement Upgrading. Mphil Thesis. Stellenbosch University. Available at: http://scholar.sun.ac.za/handle/10019.1/71856.

Kovacic, Zora. 2018. “Governing Informality Through Representation: Examples from Slum Policies in Brazil and South Africa." Cities (January): 1. doi:10.1016/j.cities.2018.07.009.

Kovacic, Zora, Josephine Kaviti Musango, Lorraine Amollo Ambole, Kareem Buyana, Suzanne Smit, Christer Anditi, Baraka Mwau, et al. 2019. "Interrogating Differences: A Comparative Analysis of Africa's Informal Settlements." World Development 122: 614-627. doi:10.1016/j.worlddev.2019.06.026.

Kovacic, Zora, Suzanne Smit, Josephine Kaviti Musango, Alan Colin Brent, and Mario Giampietro. 2016. "Probing Uncertainty Levels of Electrification in Informal Urban Settlements: A Case from South Africa." Habitat International 56: 212-221. doi:10.1016/j.habitatint.2016.06.002.

Marres, Noortje. 2005. "Issues Spark a Public Into Being: A Key but Often Forgotten Point of the Lippmann-Dewey Debate." In Making Things Public: Atmospheres of Democracy, edited by Bruno Latour and Peter Weibel, $208-217$. Cambridge, MA: MIT Press.

Marres, Noortje. 2007. "The Issues Deserve More Credit: Pragmatist Contributions to the Study of Public Involvement in Controversy." Social Studies of Science 37 (5): 759-780. doi:10.1177/0306312706077367.

Martinez-Alier, Joan, Isabelle Anguelovski, Patrick Bond, Daniela Del Bene, Federico Demaria, Julien Francois Gerber, Lucie Greyl, et al. 2014. "Between Activism and Science: Grassroots Concepts for Sustainability Coined by Environmental Justice Organizations." Journal of Political Ecology 21 (1 A): 19-60. doi:10.2458/v21i1.21124.

McFarlane, Colin, and Alex Vasudevan. 2014. "Informal Infrastructures." In The Routledge Handbook of Mobilities, edited by Peter Adey, David Bissell, Kevin Hannam, Peter Merriman, and Mimi Sheller, 256-264. London: Routledge.

Mukhija, Vinit. 2001. "Enabling Slum Redevelopment in Mumbai: Policy Paradox in Practice." Housing Studies 16 (6): $791-$ 806. doi:10.1080/02673030120090548.

Njenga, Mary. 2018. "Banning Charcoal Isn't the Way to Go, Kenya Should Make It Sustainable." The Conversation, May 2018. https://theconversation.com/banning-charcoal-isnt-the-way-to-go-kenya-should-make-it-sustainable-95610.

Ostrom, Elinor. 2005. Understanding Institutional Diversity. Princeton: Princeton University Press.

Rawls, John. 1971. A Theory of Justice. Boston: Harvard University Press.

Rittel, Horst W., and Melvin M. Webber. 1973. "Dilemmas in a General Theory of Planning." Policy Science 4: 155-169.

Roy, Ananya. 2005. "Urban Informality: Toward an Epistemology of Planning." Journal of the American Planning Association 71 (March): 147-158. doi:10.1080/01944360508976689.

Roy, Ananya, and Nezar AlSayyad. 2004. Urban Informality: Transnational Perspectives from the Middle East, Latin America, and South Asia, edited by Ananya Roy and Nezar AlSayyad. Lanham: Lexington Books.

Scott, James. 1998. Seeing Like a State: How Certain Scheme to Improve the Human Condition Have Failed. New Haven: Yale University Press.

Shi, Linda, Eric Chu, Isabelle Anguelovski, Alexander Aylett, Jessica Debats, Kian Goh, Todd Schenk, et al. 2016. "Roadmap Towards Justice in Urban Climate Adaptation Research." Nature Climate Change 6 (2): 131-137. doi:10. 1038/nclimate2841.

Smit, Suzanne, Josephine Kaviti Musango, Zora Kovacic, and Alan Colin Brent. 2019. "Towards Measuring the Informal City: A Societal Metabolism Approach." Journal of Industrial Ecology 23 (3): 674-685. 